\title{
INTEGRAL EVALUATION OF EFFECTIVENESS OF THE RENEWAL TREATMENT OF PATIENTS WITH ISCHEMIC HEART DISEASE AFTER MYOCARDIUM SURGICAL REVASCULARIZATION
}

\author{
Olena Kolodenko
}

Ukrainian Research Institute of Medical Rehabilitation and

Balneology of Ministry of Health of Ukraine

6 Lermontovskiy lane, Odessa, Ukraine, 65014

Vladimir Kolodenko

Medical and health complex "Bila akacia"

59 Frantsuzkyi blvd., Odessa, Ukraine, 65058

Konstantin Babov

Ukrainian Research Institute of Medical Rehabilitation and

Balneology of Ministry of Health of Ukraine

6 Lermontovskiy lane, Odessa, Ukraine, 65014

\begin{abstract}
Cardiovascular diseases are the one of main causes of lethality in all developed countries. In the structure of this group of diseases ischemic heart disease (IHD) occupies the leading place. In the last decade methods of myocardium surgical revascularization that allow to remodel the myocardium essentially and to increase its functional features significantly are developed. Alongside with it, myocardium surgical revascularization doesn't eliminate main causes of atherosclerotic diseases. Ineffective rehabilitation, including insufficient management of main factors of the cardiovascular risk may essentially decrease results of this operation.

The aim of the study was to elaborate the integral evaluation of the effectiveness of the renewal treatment of patients with IHD after myocardium surgical revascularization. For this aim we offer to use metabolic (leptin, HOMA index, atherogenicity index) and clinical-functional indices (body mass index, physical working ability and ejection fraction (EF) of the left ventricle, anxiety and depression level) before and after the renewal treatment and the result - integral index (I), calculated by the formula: $\mathrm{I}=\frac{\mathrm{M}_{(1+, 2, . .+\mathrm{n})}+\mathrm{F}_{(1+, 2, . .+\mathrm{n})}}{\mathrm{N}}$, where $\mathrm{M}_{(1+2+\mathrm{n})}$ - metabolic (leptin, HOMA index, atherogenicity index) indices, $\mathrm{F}_{(1+2+\mathrm{n})}-$ functional and anthropometric ones (BMI, physical working ability, and EF of the left ventricle).

The use of the integral index before the renewal treatment allows to elaborate the effective rehabilitation program, and after to study the effectiveness of elaborated complexes and to decrease risks of IHD progression.

Keywords: Ischemic heart disease, renewal treatment, surgical revascularization, effectiveness, integral evaluation.
\end{abstract}

\section{Introduction}

Among methods of surgical treatment of ischemic heart disease (IHD) the most often used are aortocoronary (ACB) and mammary bypass (MCB), intra-skin interventions on coronary vessels [1]. The aim of any of aforesaid cardiovascular interventions is a renewal of the coronary blood circulation, elimination of mean clinical manifestations of IHD, increase of operated patients' life quality and duration, increase of their physical working ability [2]. According to the data of many authors, myocardium surgical revascularization (MSR) in 75-85\% of cases takes off from the pain syndrome, increases the life quality and 5-year prognosis of survivability. Alongside with it, MSR doesn't eliminate main causes of atherosclerotic diseases. Ineffective rehabilitation, including insufficient management of main factors of the cardiovascular risk may essentially decrease results of this operation $[3,4]$.

Despite the fact that operations on myocardium revascularization are directed on the working ability renewal and human life quality increase, these cardiovascular interventions themselves are the essential stress and dysadaptation factors for a patient [5]. The absence of the united strategy and tactics of the renewal treatment after myocardium surgical revascularization, and also underes- 
timation of hypodynamia and hypokinesia factors in the pathogenesis of postsurgical complications leads to IHD progression $[6,7]$. The analysis of literary data and own experience testify to the fact that the system approach, including the use of the integral evaluation of the risk of complications progression after myocardium surgical revascularization, especially at the concomitant pathology, wasn't properly developed and used in the stage renewal treatment [8].

There are well-known different methods of forecasting the development of cardiovascular complications after myocardium revascularization by the determination of cholesterol level, detection of features of stenosis and localization of the atherosclerotic plaque in coronary arteries; stenosis type, myocardium ischemia degree by data of Holter monitoring of an electrocardiogram; analysis of the speed of nitrogen-containing preparation metabolism; study of polymorphism genotypes and other $[9,10]$. But these methods don't have the complex approach to the integral evaluation of patients with IHD after myocardium surgical revascularization and are difficult in use at the renewal treatment stage.

\section{Aim of research}

To elaborate the integral evaluation of the effectiveness of the renewal treatment of patients after myocardium surgical revascularization.

\section{Materials and methods of research}

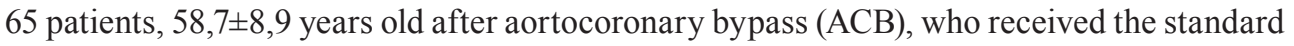
medicamental therapy, namely nitrates, beta-blockers, calcium antagonists, ATE inhibitors, disagregants, diuretics, hypolipidemic drugs and the complex of sanatorium rehabilitation were under observation at the treating-recovery complex "Bila acacia" (Odessa city, Ukraine). Patients of the first group (17 persons) were admitted for rehabilitation in 7 days after the surgical treatment at the absence of postsurgical complications at severe concomitant diseases. The contraindications for early admission at the specialized rehabilitation department were: often and long attacks of angina of rest and effort, unstable angina; recent myocardium infarction; insufficiency of blood circulation of IV f.c. by NYHA; expressed rhythm disorders; expressed arterial hypertension with an injury of inside organs, that is badly subjected to correction; postsurgical complications; concomitant diseases, accompanied by fever; residual phenomena of thromboembolia in cerebral vessels. Patients of the second group (48 persons) were admitted for rehabilitation in 1-2 months after the operation. The research algorithm (before and after treatment) included the collection of anamnesis, dynamic clinical observation of objective and subjective state of patients, laboratory diagnostics by the standard methods [11] (biochemical blood analysis (aspartat-aminotransferase alanine-aminotransferase, creatinine, phosphokinase, troponin, C-reactive protein, lipidogram, blood sugar, insulin, HOMA index, leptin and instrumental research methods (ECG, heart US, Holter monitoring of ECG, measuring of arterial pressure, heart contractions frequency, six-minute test (SMT)). For evaluating the psychological state, HADS and Spielberg anxiety scales were used, life quality was evaluated by SF-36 scale.

For the integral evaluation before and after the renewal treatment metabolic and clinical functional indices before and after treatment, namely, metabolic (leptin, HOMA index, atherogenicity index) and clinical-functional (body mass index, (BMI) physical working ability and ejection fraction (EF) of the left ventricle, anxiety and depression level) and the result - integral index (I) was calculated by the formula:

$$
\mathrm{I}=\frac{\mathrm{M}_{(1+, 2+. . \mathrm{n})}+\mathrm{F}_{(1+2,+. \mathrm{n})}}{\mathrm{N}}
$$

where $\mathrm{M}_{(1+2+n)}$ - metabolic indices (leptin, HOMA index, atherogenicity index); $\mathrm{F}_{(1+2+\mathrm{n})}$ - functional and anthropometric indices (BMI, physical working ability and ejection fraction (EF) of the left ventricle); $\mathrm{N}$ - number of calculated indices.

At that the quantitative evaluation of indices from 1 to 3 points was taken into account (Table 1). 
Table 1

Criteria of point evaluation of clinical indices

\begin{tabular}{|c|c|c|c|}
\hline \multirow[b]{2}{*}{ Indices } & \multicolumn{3}{|c|}{ Criteria } \\
\hline & $\begin{array}{c}\text { Low } \\
\text { (1 point) }\end{array}$ & $\begin{array}{l}\text { Critical } \\
\text { (2 points) }\end{array}$ & $\begin{array}{c}\text { High } \\
\text { (3 points) }\end{array}$ \\
\hline \multicolumn{4}{|l|}{ 1. Metabolic } \\
\hline 1.1. Leptin level, mcg/l & $\leq 18,55$ & $18,55-20,69$ & $\geq 20,69$ \\
\hline 1.2. Atherogenicity level & $\leq 4,36$ & $4,36-5,21$ & $\geq 5,21$ \\
\hline 1.3. HOMA index & $\leq 4,6$ & $4,6-10,9$ & $\geq 10,9$ \\
\hline \multicolumn{4}{|l|}{ 2. Clinical-functional } \\
\hline 2.1. BMI kg/m² & $\leq 23,1$ & $23,1-34,4$ & $\geq 34,4$ \\
\hline 2.2. Physical working ability (SMT) & $\geq 310$ & $310-265$ & $\leq 265$ \\
\hline 2.3. EF, \% & $\geq 68,1$ & $55,3-68,1$ & $\leq 55,3$ \\
\hline 2.4. Anxiety (by HADS), points & $0-7$ & $8-10$ & $\geq 11$ \\
\hline 2.5. Depression (by HADS), points & $0-7$ & $8-10$ & $\geq 11$ \\
\hline
\end{tabular}

The renewal treatment (RT) course included: the saving-training regime of moving activity, climate-, diet-, physiotherapy (magnitolazerotherapy), balneotherapy ("dry" carbonic bathes) and TFC. The treatment course was 21 days.

\section{Results}

At admission to RT the absence of complaints, connected with the complete regression of IHD symptoms after surgical MR was observed in $15,8 \%$ of patients, but $35,4 \%$ of patients complained for discomfort in the precordial zone, $64,3 \%$ of patients suffered from general weakness and fast tiredness, 10,7\% observed short-term pressing pains behind the breastbone at physical loads, inessential short breath was observed in $25,9 \%$ of patients, $17,1 \%$ complained for tachycardia, 20,3\% - for "breaks" in the heart work.

In $55,2 \%$ of patients was observed an excessive weight before RT, BMI in patients of the second group was by 7,0 \% higher (Table 2). Before RT in both groups of patients were revealed metabolic changes - the increase of atherogenicity index in the first group by $11,3 \%$ more), HOMA and leptin (in the second group by $21,6 \%$ and by $11,2 \%$ more comparing with the first one). In patients of the second group was observed the rise of anxiety and depression levels by HADS by $33,9 \%$ and $22,5 \%$ comparing with patients of the first group. We didn't observe any reliable differences at the determination of tolerance to physical loads and EF in patients of both groups. After RT we observed the reliable improvement of metabolic and clinical-functional indices (Table 2), namely the decrease of atherogenicity indices by 25,5 and $18,0 \%$ in the first and second groups, HOMA - 13,2 and 8,0 \%, leptin level $-28,7$ and 19,3 \% respectively $(\mathrm{p} \leq 0,05)$.

At the evaluation of the neuropsychic state after RT we observed the decrease of the anxiety level (by 29,1 and 25,2 \%) and depression level (by 25,4 and 21,7\%) in patients of the first and second groups, respectively. At the analysis of the dynamics of tolerance to physical loads - the increase of distance, passed by patients in six minutes - in the first and second groups by 18,1 and $10,7 \%$ respectively. The positive dynamics was also at EchoCS examination - EF increase in patients of both groups - by 9,2 and $8,2 \%$ respectively.

At the determination of the integral index at admission to RT in patients of the second group, I was by $12,5 \%$ higher, than in patients of the first one. After RT - the decrease of this index in the first group by $37,5 \%$, and in the second one - by $29,3 \%$. 
Table 2

Clinical-laboratory characteristics of examined patients that were at the sanatorium treatment

\begin{tabular}{|c|c|c|c|c|}
\hline \multirow{3}{*}{ Indices } & \multicolumn{4}{|c|}{ Groups } \\
\hline & \multicolumn{2}{|c|}{ A1 } & \multicolumn{2}{|c|}{ A2 } \\
\hline & Before RT & After RT & Before RT & After RT \\
\hline BMI kg/m² & $34,4 \pm 2,6$ & $30,9 \pm 2,2$ & $36,8 \pm 2,7$ & $34 \pm 2,7$ \\
\hline Atherogenicity index & $7.33+0,15$ & $5,46 \pm 0,09^{* *}$ & $6.51 \pm 1,18$ & $5,34 \pm 0,16^{*}$ \\
\hline HOMA index & $13,55 \pm 1,25$ & $11,76 \pm 1,34^{* *}$ & $16,47 \pm 1,18$ & $15,16 \pm 1,57$ \\
\hline Leptin, mcg/1 & $21,62 \pm 1,07$ & $15,4 \pm 1,27^{* *}$ & $25,55 \pm 3,41$ & $19,3 \pm 2,45^{*}$ \\
\hline Anxiety scale HADS (points) & $6,12 \pm 0,95$ & $4,34 \pm 1,57 * *$ & $8,20 \pm 1,73$ & $6,13 \pm 1,11^{*}$ \\
\hline $\begin{array}{l}\text { Depression scale HADS } \\
\text { (points) }\end{array}$ & $7,51 \pm 1,24$ & $5,6 \pm 1,1 * *$ & $9,2 \pm 1,2$ & $7,2 \pm 1,4^{*}$ \\
\hline $\operatorname{SMT}(\mathrm{M})$ & $262,6 \pm 30,47$ & $310,2 \pm 25,91^{* *}$ & $285,1 \pm 14,33$ & $315,5 \pm 17,47^{*}$ \\
\hline $\mathrm{EF}(\%)$ & $54,15 \pm 2,73$ & $59,14 \pm 2,12 *$ & $54,37 \pm 2,81$ & $58,85 \pm 2,44^{*}$ \\
\hline Integral index (I) & $2,0 \pm 0,75$ & $1,25 \pm 0,37 * *$ & $2,25 \pm 0,56$ & $1,59 \pm 0,50 *$ \\
\hline
\end{tabular}

Note: The difference of indices is reliable comparing with: * - before and after treatment $(p<0,05)$; ** - between groups after treatment $(p<0,05)$

\section{Discussion of results}

Literary data prove the effectiveness of physical rehabilitation of patients after cardiosurgical interventions, who are at 2 or 3 rehabilitation level and have practically no complications risk after ACB [12]. But rehabilitation protocols of cardiorehabilitation, used at the early stage, are subjective. More often the physical rehabilitation after ACB includes respiratory exercises, because it is used to think, that physical exercises must be avoided during at least 3 months after surgery [13]. From the other side, if one avoids physical activity in first weeks after surgery, it results in the more expressed atrophy of breast muscles and shoulder girdle [14]. That is just why, we find it necessary to realize the early RT, and the use of the integral evaluation helps to elaborate RT complexes and to determine its effectiveness. Thus, according to our data, in patients, admitted to hospital after myocardium surgical revascularization was observed the essential increase of health state, because the surgical intervention eliminates the anatomic base of pathology and leads to hemodynamics and life quality increase that is noted in works by many authors $[15,16]$.

Among risk factors of IHD development in examined persons prevailed insufficient physical activity that resulted in BMI increase, especially in the group of patients, who didn't receive the early RT. As it is known, obesity is considered by many researchers as a predictor of angina return development and late myocardium infarction after aortocoronary bypass [17]. At the same time insulin resistance or hyperinsulinemia that are just risk factors of cardiovascular diseases, favoring dyslipidemia development, strengthening rheological properties, hemostasis and water balance disorder, often develop in patients at the background of obesity [18], that is distinctly traced also in our studies - the increase of HOMA index and leptin level in patients of the second group is more than in ones of the first group. The lower atherogenicity indices in patients of the second group comparing with ones of the first group before RV are connected, from our point of view, with the regular intake of hypolipidemic drugs (recommended at the stationary stage), but after RT the reliable decrease of this index was observed in patients of the first group after all.

Data of the Institute of sport medicine, prophylaxis and rehabilitation testify to the fact that the early (1-2 weak after surgery) start of the adapted program of cardiorehabilitation is safe, accelerates recovery, doesn't increase problems with the sternum and favors psychological recovery [19]. It is used to think that depression can be both a factor of myocardium infarction development 
and a cause of the complicated clinical course after cardiosurgical operations [20]. In our study at the evaluation of the neuropsychic state in patients of the second group the indices of anxiety and depression before RT were reliably higher, and after TR - their reliable decrease was observed in patients of the first group that also testifies to the necessity of the early renewal treatment.

In was proved, that the renewal of the myocardium contraction ability after ACB is realized gradually that is connected also with the state of myocardium devitalization [21], so EchoCG with EF determination was carried out in 3-6 months after the surgical intervention. That is just why patients before RT had no essential differences of EF between groups, and after the treatment we observed the positive dynamics, especially in the first group.

At the complex evaluation of patients before RT the integral index (I) in the first group was by $12, \%$ lower, comparing with the second one that proves all aforesaid about the fact that patients, who don't receive the correspondent early renewal treatment have a higher risk of IHD progression, considered by us as IHD critical progression. After the renewal treatment in patients of both groups was observed the low level of IHD progression, better result, namely the reliable decrease $(\mathrm{p} \leq 0,05)$ of I by $8,2 \%$ comparing with patients from the second group.

The shortcoming of our research is an insufficient term of observation of patients after the renewal treatment, at the same time it is necessary to carry out the correlative analysis of factors that influence IHD progression.

\section{Conclusions}

1. The early stage of RT in patients with IHD after myocardium surgical revascularization is a necessary part of medical rehabilitation of this category of patients that allows to realize the timely correction of metabolic, neuropsychic and functional deviations and optimization of the renewal treatment.

2. The integral evaluation before the beginning of RT allows to elaborate the effective renewal treatment of these patients.

3. The evaluation of the effectiveness of the renewal treatment of patients with IHD after myocardium surgical revascularization is an important problem of medical rehabilitation.

\section{References}

[1] Akchurin, P. C., Shiryayev, A. A., Galyautdinov, D. M. et. al. (2014). Effektivnost koronarnoy khirurgii: rezul'taty 20-letnego nablyudeniya. Kardiologiya i serdechno-sosudistaya khirurgiya, 1, 10-14.

[2] Aronov, D. M., Bubnova, M. G. (2010). Realnyi put snizheniya v Rossii smertnosti ot ishemicheskoy bolezni serdtsa. Kardiosamatika, 1, 11-17.

[3] Podpalov, V. P. (2011). Gruppy vysokogo riska smertnosti ot bolezney sistemy krovoobrashcheniya u lits s arterialnoy gipertenziyey (po dannym desyatiletnego kogortnogo issledovaniya). Kardiologiya $v$ Belarusi, 4, 75-85.

[4] Lutay, M. I. (2011). Vedeniye bolnykh s ishemicheskoy boleznyu serdtsa i soputstvuyushchey arterial'noy gipertenziyey v Ukraine. Rezultaty issledovaniya PRESTIZH. Ukrainskyi kardiologichniy zhurnal, 1, 25-36.

[5] Marchenko, O. K., Yevstratova, I. N., Alshbul, M. (2012). Fizychna reabilitatsiya osib iz ishemichnoyu khvoroboyu sertsya z syndromom insulinorezystentnosti. Teoriya ta metodyka fizychnoho vykhovannya i sportu, 1, 77-80.

[6] Oganov, R. G. (2012). Profilakticheskaya kardiologiya: nadezhdy i realnost. Zdravookhraneniye, $9,60-67$.

[7] Wijns, W., Kolh, P., Danchin, N., Di Mario, C., Falk, V., Folliguet, T. et. al. (2010). Guidelines on myocardial revascularization: The Task Force on Myocardial Revascularization of the European Society of Cardiology (ESC) and the European Association for Cardio-Thoracic Surgery (EACTS). European Heart Journal, 31 (20), 2501-2555.

[8] Yusuf, S., Anand, S. (2010). Deciphering the Causes of Cardiovascular and Other Complex Diseases in Populations: Achievements, Challenges, Opportunities, and Approaches. Progress in Cardiovascular Diseases, 53 (1), 62-67. doi: 10.1016/j.pcad.2010.02.001 
[9] Kaski, J. C., Fernandez-Berges, D. J., Consuegra-Sanchez, L., Fernandez, J. M. C., Garcia-Moll, X., Mostaza, J. M. et. al. (2010). A comparative study of biomarkers for risk prediction in acute coronary syndrome-Results of the SIESTA (Systemic Inflammation Evaluation in non-ST-elevation Acute coronary syndrome) study. Atherosclerosis, 212 (2), 636-643. doi: 10.1016/j.atherosclerosis.2010.06.026

[10] Joosten, M. M., Pai, J. K., Bertoia, M. L., Rimm, E. B., Spiegelman, D., Mittleman, M. A., Mukamal, K. J. (2012). Associations Between Conventional Cardiovascular Risk Factors and Risk of Peripheral Artery Disease in Men. JAMA, 308 (16), 1660-16167. doi: 10.1001/jama.2012.13415

[11] Lutsyk, B. D. (2008). Klinichna laboratorna diahnostyka. Lviv: PP Soroka, 264.

[12] Shutt, A., Bolotova, E. V., Xale, M. (2005). The role of physical activity in secondary prevention of coronary heart disease. Cardiology, 7, 83-86.

[13] O’Connor, C. M., Whellan, D. J., Lee, K. L., Keteyian, S. J., Cooper, L. S., Ellis, S. J. et. al. (2009). Efficacy and Safety of Exercise Training in Patients With Chronic Heart Failure. JAMA, 301 (14), 1439-1450. doi: 10.1001/jama.2009.454

[14] El-Ansary, D., Waddington, G., Adams, R. (2007). Trunk stabilisation exercises reduce sternal separation in chronic sternal instability after cardiac surgery: a randomised cross-over trial. Australian Journal of Physiotherapy, 53 (4), 255-260. doi: 10.1016/s0004-9514(07)70006-5

[15] Hammill, B. G., Curtis, L. H., Schulman, K. A., Whellan, D. J. (2010). Relationship Between Cardiac Rehabilitation and Long-Term Risks of Death and Myocardial Infarction Among Elderly Medicare Beneficiaries. Circulation, 121 (1), 63-70. doi: 10.1161/circulationaha.109.876383

[16] Yang, L.-X., Zhou, Y.-J., Wang, Z.-J. et. al. (2014). Impact of invasive treatment strategy on health-related quality of life six months after non-ST-elevation acute coronary syndrome. Journal of Geriatric Cardiology, 11 (3), 206-211.

[17] Dyuzhikov, A. A., Kartashov, A. A. (2013). Vliyaniye ozhireniya i rannikh narusheniy uglevodnogo obmena na effektivnost aortokoronarnogo shchuntirovaniya v bolnykh ishemicheskoy boleznyu serdtsa. Prakticheskaya meditsina, 2 (67), 66-71.

[18] Marso, S. P., McGuire, D. K., Zinman, B., Poulter, N. R., Emerson, S. S., Pieber, T. R. et. al. (2016). Design of DEVOTE (Trial Comparing Cardiovascular Safety of Insulin Degludec vs Insulin Glargine in Patients With Type 2 Diabetes at High Risk of Cardiovascular Events) - DEVOTE 1. American Heart Journal, 179, 175-183. doi: 10.1016/j.ahj.2016.06.004

[19] Bjarnason-Wehrens, B. (2009). Kardiologische Rehabilitation in Europa. Clinical Research in Cardiology Supplements, 4 (2), 82-88. doi: 10.1007/s11789-009-0062-3

[20] Mark, D. B., Knight, J. D., Velazquez, E. J., Wasilewski, J., Howlett, J. G., Smith, P. K. et. al. (2014). Quality-of-Life Outcomes With Coronary Artery Bypass Graft Surgery in Ischemic Left Ventricular Dysfunction. Annals of Internal Medicine, 161 (6), 392-399. doi: 10.7326/m13-1380

[21] Graham, I., Atar, D., Borch-Johnsen, K., Boysen, G., Burell, G., Cifkova, R. et. al. (2007). Fourth Joint Task Force of the European Society of Cardiology and Other Societies on Cardiovascular Disease Prevention in Clinical Practice (Constituted by representatives of nine societies and by invited experts). European Journal of Cardiovascular Prevention \& Rehabilitation, 14 (2), E1-E40. doi: 10.1097/ 01.hjr.0000277984.31558.c4 